\title{
PENGARUH DESAIN LOBBY TERHADAP EKSISTENSI UNIVERSITAS MATANA DI GADING SERPONG
}

\author{
Natasha Shania Abigail ${ }^{1}$, Rahmania Indriyanti ${ }^{2}$ \\ Program Studi Arsitektur, FSTEM, Universitas Matana ${ }^{1,2}$
}

\begin{abstract}
Abstrak
Gading Serpong terkenal dengan kawasan yang mencakup banyak mahasiswa didalamnya disebabkan banyaknya area-area universitas yang ada disekitarnya. Beberapa diantaranya telah dikenal oleh banyak masyarakat akibat dari umur universitas tersebut. Matana muncul menjadi universitas kurang dalam kurun waktu 10 tahun sehingga dapat dikatakan sebagai pendatang baru. Layaknya sebuah universitas harus memenuhi kriteria-kriteria yang dianjurkan dan salah satunya adalah fasilitas lobi. Lobi merupakan titik awal dalam sebuah universitas. Banyak kegiatan yang dapat dilakukan di lobi. Pada tahun 2018 universitas matana berhasil membangun sebuah lobi yang berada di sudut persimpangan jalan. Hal ini dapat menyebabkan pengaruh yang signifikan terhadap eksistensi universtas di kawasan Gading serpong. Melalui penelitian ini diharapkan memberi pengetahuan mengenai pengaruh lobi terhadap eksistensi universitas dikawasan tersebut. Hasil penelitian ini menun jukan bahwa ternyata memang ada hubungan yang kuat dan signifikan dengan $r=0.685$ dan $t=6,55$, antara lobi matana dan pengaruhnya terhadap eksistensi universitas di kawasan Gading Serpong sebesar $47 \%$.
\end{abstract}

Kata Kunci : desain lobby, eksistensi, branding, kampus.

\begin{abstract}
Gading Serpong is famous for its area which includes many students in it due to the many university areas around it. Some of them have been recognized by many people as a result of the age of the university. Matana emerged as a university for less than 10 years so that he could be said to be a newcomer. Just like a university must meet the recommended criteria and one of them is a lobby facility. The lobby is the starting point in a university. Many activities can be done in the lobby. In 2018 the Matana University succeeded in building a lobby on the corner of a crossroads. This can cause a significant influence on the existence of universities in the Gading Serpong area. Through this research, it is expected to provide knowledge about the influence of lobbying on the existence of universities in the area. The results of this study indicate that there is indeed a strong and significant relationship with $r=0.685$ and $t=6.55$, between lobbying matana and its influence on the existence of universities in the Gading Serpong area by $47 \%$.
\end{abstract}

Keywords : lobby design, existence, branding, campus. 


\section{Pendahuluan}

Pengaruh Lobi dapat dilihat dari dua hal yaitu Lobi dan Eksistensi. Lobby adalah sebuah ruang yang terdapat pada bangunan yang berfungsi sebagai ruang peralihan antara ruang luar dan ruang dalam bangunan (Arsitag).

1. Akses utama sebuah bangunan, Lobby adalah tempat penerima pengunjung untuk mendapatkan informasi, menyelesaikan masalah administrasi dan keuangan (Aji Sadara).

2. Ruangan yang cukup luas. Lobby dengan bentuk persegi dengan luasan yang besar. Bangunan terasa sangat luas dan pola lantai yang digunakan juga berupa kotak sehingga bangunan terkesan sedikit kaku dan berbentuk persegi ini akan memberi nuansa statis, stabil, dan formal (Gilles Ronin 2009)

3. Ruang transparan (tidak tertutup), Material kaca mendominasi dinding lobby sehingga membuat ruangan terlihat terbuka dan terang. (Arean Moestaedi, 2001)

4. Kapasitas Lobby yang luas menjadi sejuk dan tidak sesak. Udara di dalam ruangan dapat terkontrol dengan baik (Cindy Colemen, 2002)

Ada lima atribut yang muncul dari pengaruh eksistensi universitas. Atribut tersebut adalah: mempunyai karakter, mudah dikenali, citra visual, berinteraksi, luas dan besar.

1. Mempunyai karakter Eksistensi sebagai pemikiran manusia yang memanfaatkan dan mengatasi seluruh pengetahuan objektif (Karl Jaspers)

2. Mudah dikenali

3. Citra Visual Eksistensi adalah keberadaan, kehadiran yang mengandung unsur bertahan (KBBI).

4. Berinteraksi, Eksistensi adalah suatu proses yang dinamis, suatu, menjadi atau mengada (Abidil Zaenal)

5. Luas dan Besar Kelima hal ini menjadi variable $Y$ (dependen) dari penelitian ini .

Interaksi bangunan lobi dengan kawasan sekitarnya mampu menaikan eksistensi bangunan dikawasan tersebut. Dengan tipologi bangunan universitas sudah selayaknya lobi hadir menjadi salah satu fasilitas yang wajib dimiliki universitas.

\section{Metode Penelitian}

Untuk mendapatkan ada atau tidaknya pengaruh, maka digunakan metode kuantitatif. Pengumpulan data diadakan dengan kuisioner terhadap 50 responden yang berada disekitar kawasan Gading Serpong pada saat jam kuliah dan selesai kuliah yaitu siang dan malam hari.

Data lalu di proses dengan software SPSS, dengan menguji validitas dan realibilitas data dan menguji hipotesis yang meliputi uji korelasi, uji signifikansi, koefisien determinasi dan uji regresi sederhana (Sugiyono, 2007) 
Berikut hipotesis sementara: $t$ hitung > t tabel ; Ho ditolak, Ha diterima, terdapat pengaruh yang signifikan antara lobi dan eksistensi universitas matana.

t hitung < t tabel ; Ho diterima, Ha ditolak, tidak terdapat pengaruh yang signifikan antara lobi dan eksistensi universitas matana.

Ho:tidak signifikan Ha: siginifikan

\begin{tabular}{|c|c|}
\hline INDIKATOR & PARAMETER \\
\hline $\begin{array}{l}\text { A. AKSES } \\
\text { UTAMA SEBUAH } \\
\text { BANGUNAN }\end{array}$ & $\begin{array}{l}\text { A. BERSIFAT } \\
\text { MENGUNDANG }\end{array}$ \\
\hline & $\begin{array}{l}\text { B. MUDAH } \\
\text { DIAKSES }\end{array}$ \\
\hline $\begin{array}{ll}\text { B. } & \text { RUANG } \\
\text { YANG } & \text { CUKUP } \\
\text { LUAS } & \end{array}$ & $\begin{array}{l}\text { A. PROPORSI } \\
\text { BANGUNAN LOBBY }\end{array}$ \\
\hline $\begin{array}{l}\text { C. RUANG YANG } \\
\text { TRANSPARANT }\end{array}$ & A. RUANG PUBLIK \\
\hline & $\begin{array}{l}\text { B. BERSIFAT } \\
\text { TERBUKA }\end{array}$ \\
\hline D. KAPASITAS & $\begin{array}{l}\text { A. CAKUPAN } \\
\text { PENGUNJUNG }\end{array}$ \\
\hline & B. DIMENSI RUANG \\
\hline
\end{tabular}

Gambar 1. Variabel X: Lobby

(Sumber: Observasi Lapangan, 2018)

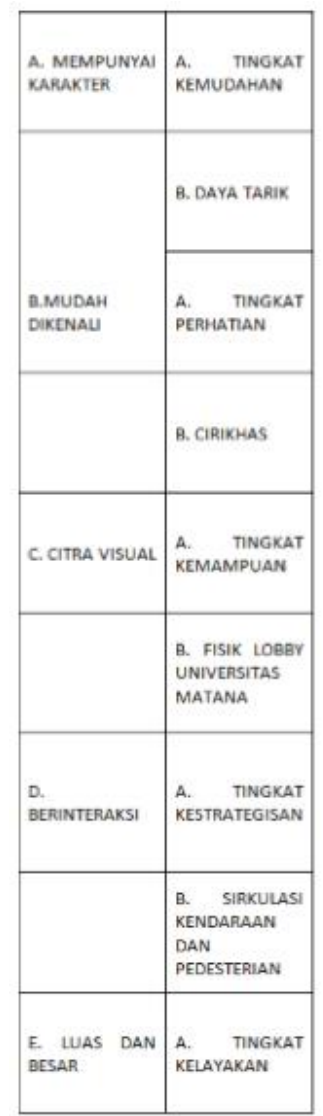

Gambac 2. Variabei Y: fksistensi

(Surmber Observasitapangan, 2018)

\section{Hasil dan Pembahasan}

Lokasi penelitian ini dilakukan pada kawasan sekitar universitas matana yang berada di Gading Serpong, Tangerang Selatan. Penelitian dilakukan di dua titik yaitu di pasar modern paramount dan sekitar universitas matana. 


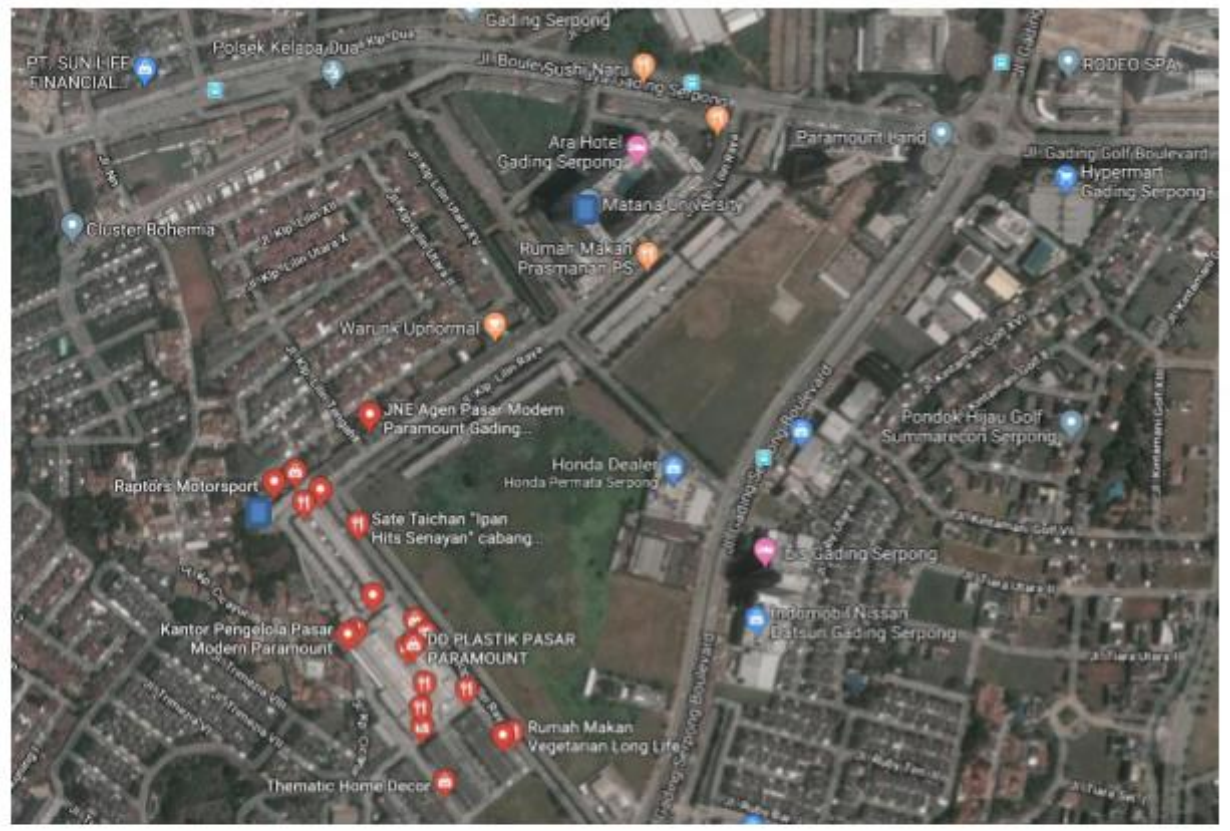

Gambar 3. Setting Lokasi Penelitian

(Sumber: Google Maps)

Dari data diatas dapat dilihat bahwa responden berasal dari $20 \%$ karyawan dan $80 \%$ mahasiswa. Dari data tersebut dapat disimpulkan bahwa $80 \%$ umur responden terdapat pada kategori B yaitu 18-22 tahun.

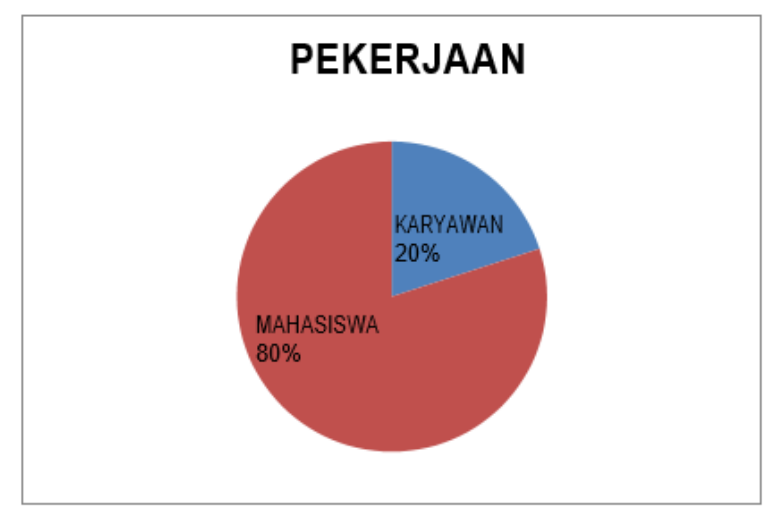

Gambar4.DiagramPekerjaan

(Sumber:Analisa 2018)

Responden yang menjawab terdiri dari $46 \%$ perempuan dan $54 \%$ laki-laki, dengan rata-rata responden remaja. Para responden berlokasi di kawasan sekitar gading serpong, tempat dimana kampus matana berada. Sehingga tidak asing lagi terhadap kampus matana. 


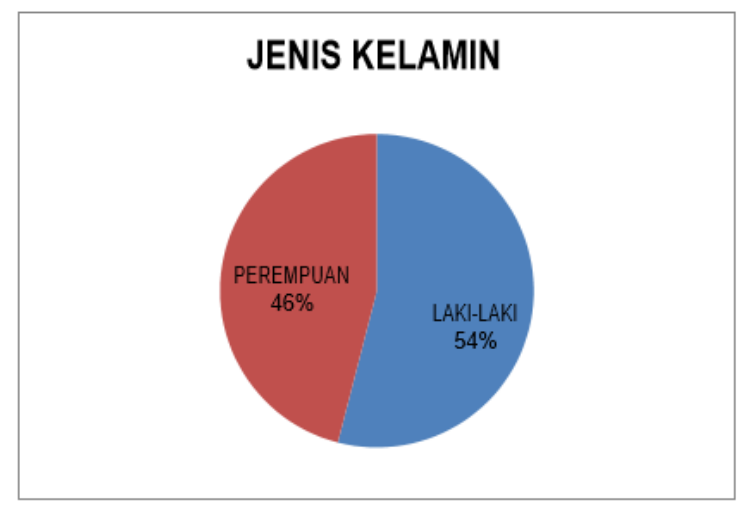

Gambar 5. Diagram Jenis Kelamin

(Sumber: Analisa 2018)

Dari grafik dan data di bawah, presentase nilai yang paling tinggi didapat oleh pernyataan tujuh. Responden menyetujui bahwa lobby matana university memiliki ukuran yang luas.

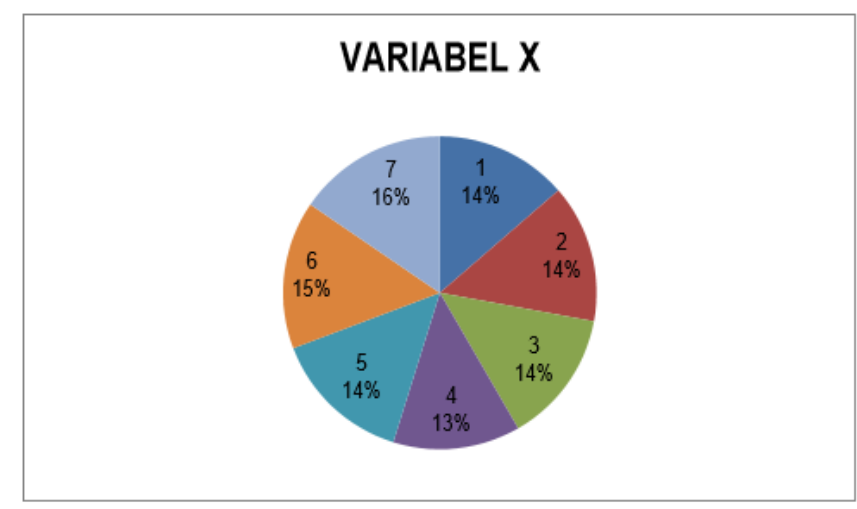

Gambar 6. Diagram X

(Sumber: Analisa 2018)

Dari grafik dan data di bawah dapat disimpulkan bahwa pernyataan tujuh dan Sembilan lebih disetujui dari pada pernyataan yang lainnya. Responden setujuh bahwa peletakan bangunan matana berada di lokasi yang strategis dan standart bangunan memiliki luas dan besar bangunan yang layak.

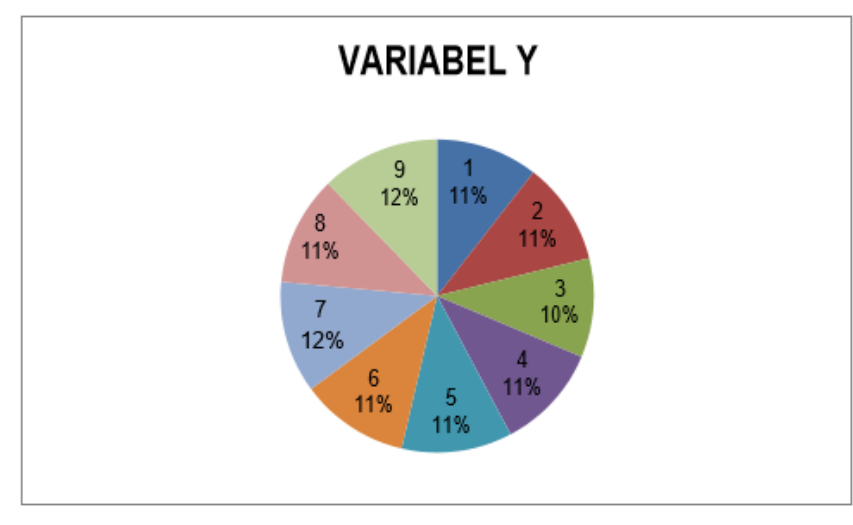

Gambar 7. Diagram Y

(Sumber: Analisa 2018) 
Dari data di Gambar 8 dapat dilihat bahwa para responden rata-rata menjawab ragu-ragu terhadap pernyataan lobby matana yang bersifat mengundang. Responden rata-rata menyetujui pernyataan bahwa lobby matana mudah diakses dikawasan gading serpong. Responden menjawab ragu-ragu terhadap pernyataan bahwa lobby matana bersifat terbuka dan dapat digunakan menjadi ruang publik. Responden menyetujui bahwa lobby matana mempunyai ukuran yang luas dan dapat mencakup banyak pengunjung sesuai fungsinya.

Dari data di Gambar 8 dapat dilihat bahwa responden setuju terhadap pernyataan bahwa bangunan tersebut dapat dipahami sebagai bangunan universitas, bangunan mampu menciptakan citra visual yang baik, bangunan mampu menciptakan citra visual universitas matana dan bangunan memiliki standart bangunan yang luas layaknya universitas.

Responden mayoritas menjawab ragu-ragu akan pernyataan bahwa universitas menjadi pusat perhatian sehimngga mudah dikenali, bangunan menggambarkan cirikhas kampus universitas matana, dan peletakan bangunan mampu memperbaiki sirkulasi jalan dan pejalan kaki disekitarnya.

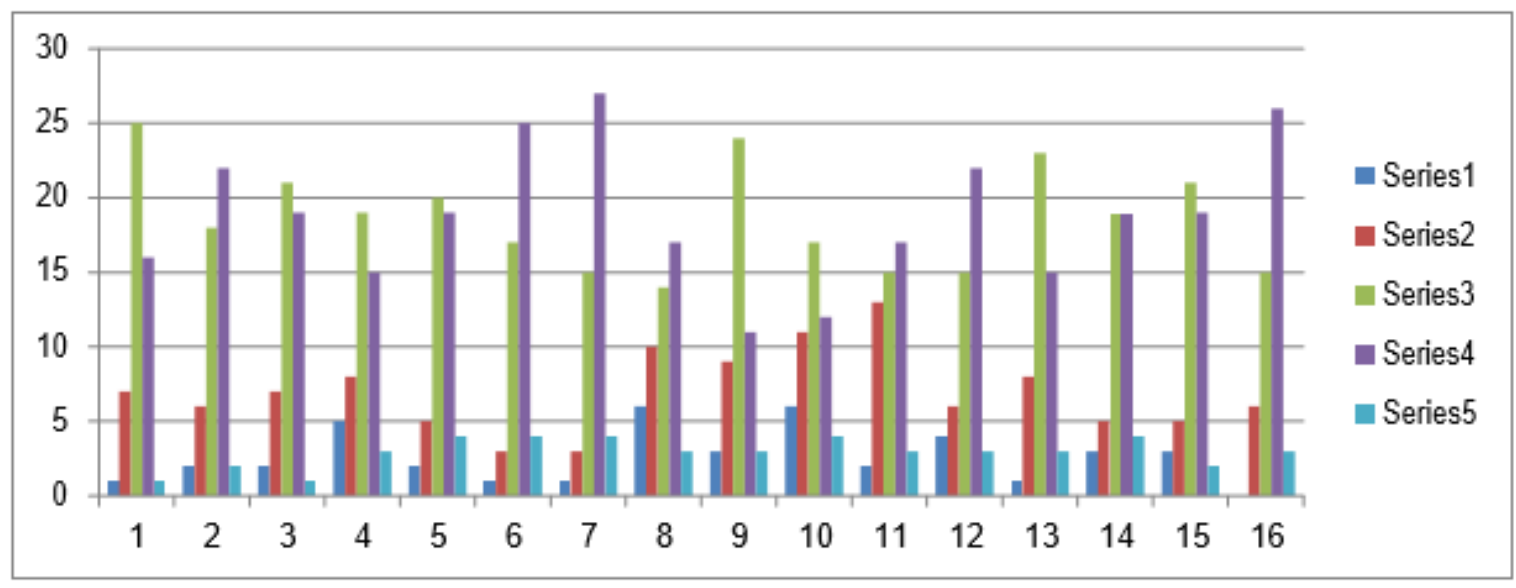

Gambar 8. Diagram Persamaan

(Sumber: Analisa 2018)

\section{Uji Validitas}

Uji validitas ini menggunakan korelasi moment dengan bantuan rumus-rumus yang dimasukkan ke dalam Microsoft excel 2010. Berikut hasil uji hipotesis dengan bantuan aplikasi SPSS.

Tabel 1. Uji Validitas Variable X

\begin{tabular}{|l|l|l|l|}
\hline ITEM PERTANYAAN & R HITUNG & R TABEL & KETERANGAN \\
\hline P1 & 0.544 & 0.238 & VALI \\
\hline P2 & 0.609 & 0.238 & VALID \\
\hline P3 & 0.625 & 0.238 & VALD \\
\hline P4 & 0.767 & 0.238 & VALD \\
\hline P5 & 0.503 & 0.238 & VALD \\
\hline P6 & 0.551 & 0.238 & VALD \\
\hline P7 & 0.597 & 0.238 & VALD \\
\hline
\end{tabular}

Tabel 2. Uji Validitas Variable Y 
Natasha Shania Abigail dan Rahmania Indriyanti

\begin{tabular}{|l|l|l|l|}
\hline ITEM PERTANYAAN & R HITUNG & R TABEL & KETERANGAN \\
\hline P8 & 0.648 & 0.238 & VALI \\
\hline P9 & 0.591 & 0.238 & VALD \\
\hline P10 & 0.792 & 0.238 & VALD \\
\hline P11 & 0.684 & 0.238 & VALD \\
\hline P12 & 0.699 & 0.238 & VALI \\
\hline P13 & 0.828 & 0.238 & VALID \\
\hline P14 & 0.586 & 0.238 & VALID \\
\hline P15 & 0.657 & 0.238 & VALID \\
\hline P16 & 0.540 & 0.238 & VALI \\
\hline
\end{tabular}

Dari hasil data diatas bahwa pernyataan-pernyataan pada variable $X$ dan $Y$ tersebut adalah valid karena lebih besar dari $r$ tabel, yaitu 0,238. Sehingga data kuesioner dapat digunakan untuk uji hipotesis.

\section{Uji Reliabilitas}

Dalam pengukuran realibilitas, dapat menggunakan rumus Cronbach's Alpha yang dibantu oleh aplikasi SPSS.

Tabel 3. Uji Realibilitas Variabel X

$\mathrm{X}$

\section{Reliability Statistics}

Cronbach's

\begin{tabular}{l|l} 
Alpha & N of Items \\
\hline .707 & 7 \\
\hline
\end{tabular}

Tabel 4. Uji Realibilitas Variabel Y.

Y

\section{Reliability Statistics}

Cronbach's

\begin{tabular}{l|l} 
Alpha & N of Items \\
\hline .858 & 9 \\
\hline
\end{tabular}

Uji dilakukan pada taraf signifikasi alpha sebesar 0,60. Instrumen dapat dikatakan reliabel apabila nilai Cronbach's Alpha lebih besar dari $r$ tabel. Sehingga data kuesioner diatas dapat digunakan dalam uji hipotesis karena baik variable $X$ maupun $Y$ alphanya $>0,60$.

\section{Uji Korelasi}

Uji korelasi dilakukan dengan metode koefisien korelasi, dengan bantuan aplikasi SPSS. 
Tabel 5. Uji Realibilitas Variabel Y.

\section{Correlations}

\begin{tabular}{|c|c|c|c|}
\hline & & $\begin{array}{l}\text { VARIABLE } \\
\mathrm{x}\end{array}$ & $\begin{array}{l}\text { VARIABLE } \\
\mathrm{Y}\end{array}$ \\
\hline \multirow{3}{*}{$\begin{array}{l}\text { VARIABLE } \\
\mathrm{X}\end{array}$} & Pearson Correlation & 1 & $.685^{* *}$ \\
\hline & Sig. (2-tailed) & & .000 \\
\hline & $\mathrm{N}$ & 50 & 50 \\
\hline \multirow{3}{*}{$\begin{array}{l}\text { VARIABLE } \\
\mathrm{Y}\end{array}$} & Pearson Correlation & $.685^{* *}$ & 1 \\
\hline & Sig. (2-tailed) & .000 & \\
\hline & $\mathrm{N}$ & 50 & 50 \\
\hline
\end{tabular}

**. Correlation is significant at the 0.01 level (2-tailed).

R hitung $>$ r tabel $=$ Ho ditolak, Ha diterima

$\mathrm{Ho}=$ tidak ada hubungan, $\mathrm{Ha}=$ ada hubungan

Tingkat hubungan $=$ kuat

Berdasarkan hasil perhitungan di atas maka terlihat bahwa koefisien korelasi sebesar 0,685 termasuk pada kategori kuat. Jadi, didapat hubungan yang kuat antara Desain Lobby Universitas Matana (variabel X) dan Eksistensi Universitas Matana (variabel Y).

\section{Koefisien Determinasi}

Untuk mengetahui seberapa besar variable $\mathrm{x}$ (lobi) mempengaruhi variable y (eksistensi universitas matana) maka kemudian dicari koefisien determinasinya yaitu dengan menggunakan rumus sebagai berikut:

$r$ hitung $=0,685 \mathrm{kd}=r 2 \times 100 \%=46,9225 \%=47 \% \mathrm{kdy}=r 2 \times 100 \%=46,9225 \%=47 \%$

Berdasarkan hasil perhitungan diatas dapat dilihat bahwa pengaruh lobi baru terhadap eksistensi universitas matana dikawasan Gading Serpong kuat dengan presentase 47\% dan sisanya 53\% dipengaruhi oleh faktor lain seperti tipologi bangunan, marketing pemasaran dll.

\section{Uji Signifikansi}

Untuk menguji signifikansi kolerasi, yaitu apakah hubungan yang ditemukan itu berlaku untuk seluruh sampel yang berjumlah 50 orang, maka perlu diuji signifikansinya.adapun hipotesisnya

\section{3}

adalah apabila $\mathrm{t}$ hitung $>\mathrm{t}$ tabel $=$ signifikan. Dengan bantuan perhitungan software SPSS maka didapatkan $t$ hitung $=6,511$ sedangkan $t$ tabel $=2,011$. Maka Ha diterima dan Ho ditolak, artinya terdapat hubungan yang signifikan antara lobi baru dan eksistensi matana dikawasan gading serpong seperti pada kurva dibawah ini. 


\section{Coefficients $^{\mathrm{a}}$}

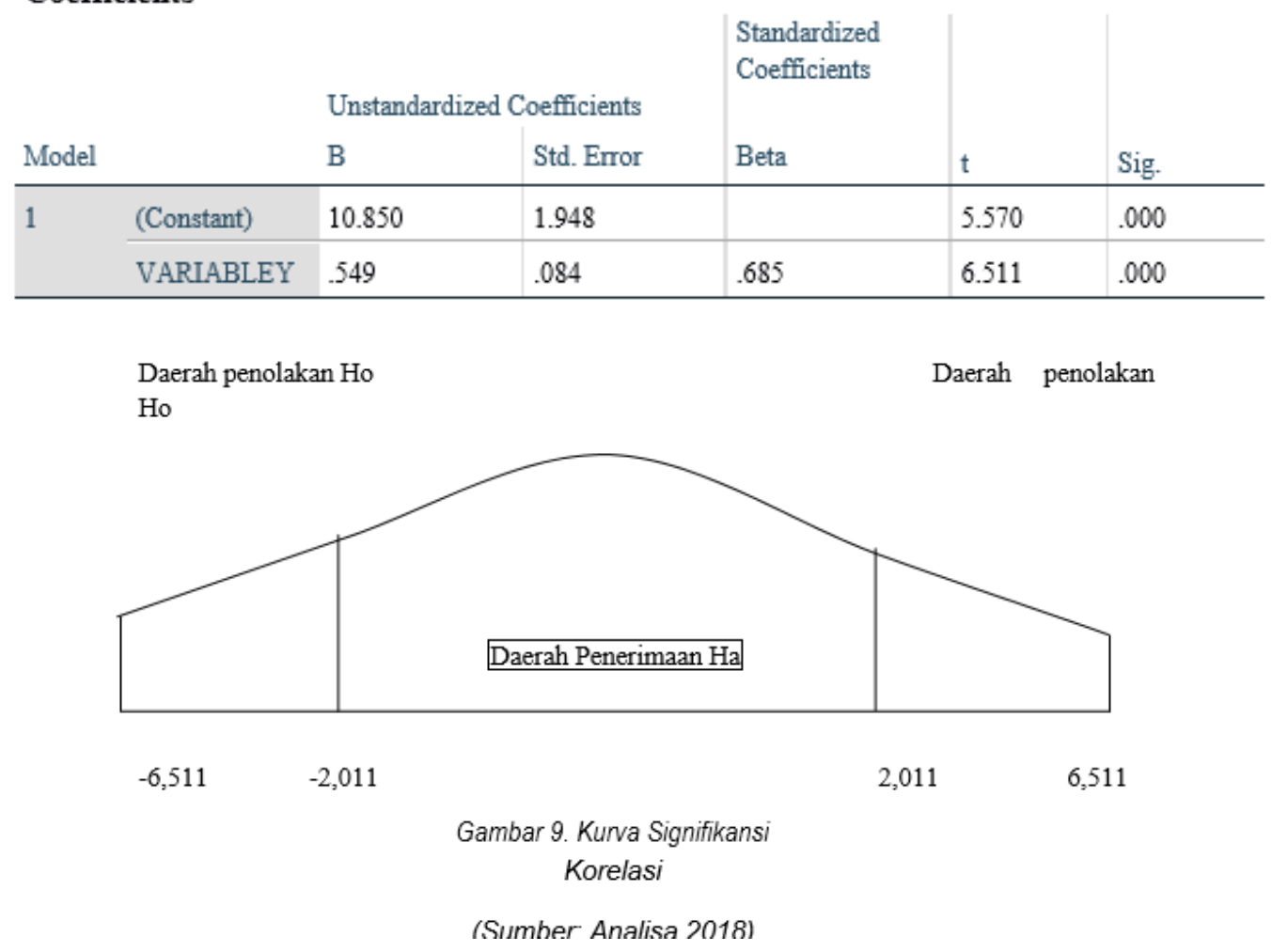

\section{Persamaan Regresi}

Selanjutnya untuk menguji seberapa hubungan lobi terhadap eksistensi universitas matana di gading serpong, maka perlu dilakukan perhitungan dengan analisa regresi linear sederhana. Bentuk persamaan regresi: $\mathrm{Sig}=0.000<0.25=$ Signifikan .

Dengan perhitungan software SPSS telah ditemukan $a=10.85$ dan $b=0.549$. Dengan demikian bentuk pengaruh anatara variable lobi terhadap eksistensi universitas matana dapat dinyatakan dengan persamaan y $=11+0.5 x$ Dari persamaan regresi diatas dapat diartikan bahwa, bila nilai lobi bertambah 1 maka nilai rata rata lobi akan bertambah 0.5 atau setiap nilai pengaruh bertambah 10 , maka nilai rata-rata eksistensi universitas matana akan bertambah 5. Misalkan jika nilai lobi sama dengan 10 maka nilai rata-rata ekesistensi universitas matana adalah regresi $Y=11+0.5(10)=16$ Garis regresi dapat digambarkan berdasarkan persamaan yang telah ditemukan adalah sebagai berikut:

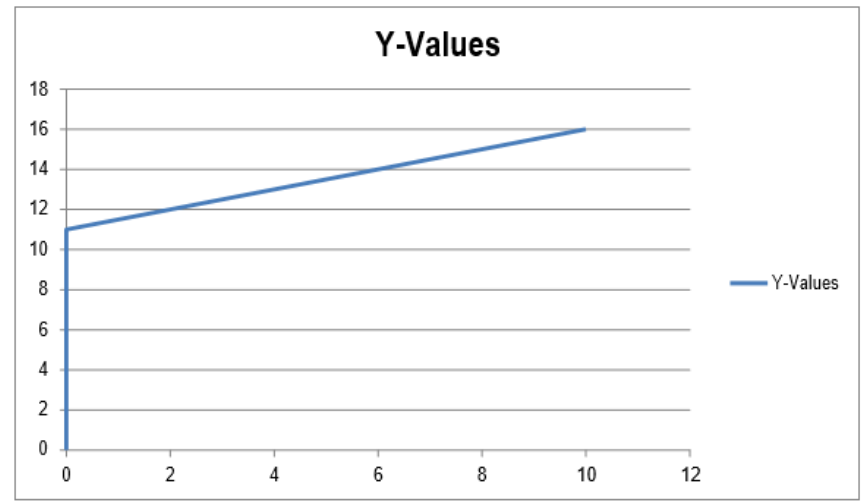

Gambar 10. Persamaan Regresi

(Sumber: Analisa 2018) 


\section{Kesimpulan}

Dari rekapitulasi data, maka didapat kesimpulan bahwa: 1. Lobi matana cukup kuat pengaruhnya terhadap eksistensi universitas matana di kawasan gading serpong. 2. Eksistensi Universitas Matana dikawasan gading serpong tergolong dapat berinteraksi dengan kawasan secara baik.

Dari hasil uji hipotesis diketahui koefisien korelasi dari penelitian ini sebesar $0.685 \%$ yang berarti bahwa terdapat hubungan yang positif antara lobi dan eksistensi universitas matana dikawasan gading serpong yang koefisien korelasinya kuat. Dilihat dari $r$ tabel bahwa untuk $n=50$ maka harga $r$ tabel= 0.238 dan ketentuannya $r$ hitung lebih kecil dari $r$ tabel ( $r$ hitung $<r$ tabel) maka Ho diterima dan Ha ditolak. Tetapi sebaliknya apabila $r$ hitung lebih besar dari $r$ tabel ( $r$ hitung $>r$ tabel) maka Ha diterima dan Ho ditolak. Ternyata $r$ hitung (0.685) lebih besar dari $r$ tabel (0.238) dengan demikian terdapat hubungan positif yang kuat anatara slobi terhadap eksistensi universitas matana dikawasan Gading Serpong. Hasil perhitungan t hitung sebesar 6,511 dan t tabel sebesar 2,011. Dengan demikian $t$ hitung $>t$ tabel, maka Ha diterima dan ho ditolak, artinya terdapat hubungan yang signifikan anatara lobi dan eksistensi universitas matana dikawasan gading serpong. Adapun besar pengaruh lobi terhadap ekesistensi universitas matana dapat diketahui dari nilai determinasi, dimana setelah dilakukan perhitungan diperoleh koefisien determinasi sebesar $47 \%$. Ini menunjukan bahwa keberpengaruhan variable $\mathrm{x}$ (lobi) terhadap variable y (ekesistensi universitas matana) di kawasan Gading Serpong sebesar 47\%, dan sisanya sebesar 53\%. Maka diperlukan beberapa upaya untuk memaksimalkan eksistensi lobi seperti:

1. Mengisi ruangan lobi dengan fasilitas seperti tempat duduk, meja, dll

2. Menyediakan ruang berkumpul di dalam lobi seperti mini café, reading spot, dll

3. Lobi sebaiknya segera di fasilitasi agar lebih jelas keberadaan universitas matana dalam bangunan tersebut

\section{Daftar Pustaka}

Gilles Ronin, (2009), Drawing For Interior Designers, A \& C Black Publisher, London, pp. 14-26, part 2 : plans \& layouts.

Arian Moestaedi, (2001), New Health Facilities Architectural Design, English Language, Instituto Monsa de Ediciones, Barcelona, Spain, pp. 86, part 10 : centre hospitalier franqois qoesnay.

Cindy Coleman, (2002), Interior Design Handbook of Proffesional Practice, Mc Graw Hill Professional Book, New York, pp. 48, part one : intelligent interiors.

Trihendradi, (2013), Langkah Praktis Menguasai Statistik untuk Ilmu Sosial Kesehatan Konsep \& Penerapannya Menggunakan SPSS, Yogyakarta.

Surjawerni, V. Wiratna. Dkk. 2012. Statistika untuk Penelitian. Halaman 196-201. Yogyakarta: Graha Ilmu.

Sugiono. 2013. Metode Penelitian Kuantitatif, Kualitatif, dan R\&D. Bandung: Alfabeta.

Trihendradi, C. 2013. Langkah Praktis Menguasai Statistik untuk Ilmu Sosial Kesehatan Konsep \& Penerapannya Menggunakan SPSS. Yogyakarta: Andi Offset. 